\title{
The Millennium Eruption of Changbaishan Tianchi Volcano is VEI 6, not 7
}

\author{
Qingyuan Yang ${ }^{1,2}$ (1) . Susanna F. Jenkins ${ }^{1,2}$. Geoffrey A. Lerner ${ }^{1,2} \cdot$ Weiran $\mathrm{Li}^{1,3} \cdot$ Takehiko Suzuki $^{4}$. \\ Danielle McLean ${ }^{5}$ - A. N. Derkachev ${ }^{6} \cdot$ I. V. Utkin ${ }^{6} \cdot$ Haiquan Wei $^{7}$. Jiandong Xu' B Bo Pan $^{7}$
}

Received: 21 June 2021 / Accepted: 27 August 2021 / Published online: 23 October 2021

(C) The Author(s) 2021

\begin{abstract}
The Millennium Eruption (AD 946-947) of Changbaishan Tianchi Volcano is one of the largest known eruptions in recorded history. With the help of previously published isopachs and distal ash thicknesses, we re-calculate the bulk volume of its distal eruptive product, the B-Tm ash, as $27-62 \mathrm{~km}^{3}$ and the total eruption volume as $40-98 \mathrm{~km}^{3}$. The updated volume estimates are around half of those estimated by previous studies of this seminal eruption. Our work shows that the Millennium Eruption is a VEI-6 eruption, rather than VEI-7 as previously envisaged, and its magnitude is also lower than previously thought. This has implications for regional frequency-magnitude relationships and may also partially explain the limited regional, rather than global, climatic effects of the Millennium Eruption.
\end{abstract}

Keywords Millennium eruption $\cdot$ Changbaishan tianchi volcano $\cdot$ Isopachs $\cdot$ B-Tm ash $\cdot$ Tephra volume $\cdot$ VEI

\section{Introduction}

The Millennium Eruption (ME) of Changbaishan Tianchi Volcano, on the border of China and North Korea, took place in AD 946-947 (Xu et al. 2013; Oppenheimer et al. 2017). Previous works have classified it as a VEI-7 (100 to

Editorial responsibility: J. Fierstein

Qingyuan Yang

qingyuan.yang@ntu.edu.sg

1 Earth Observatory of Singapore, Singapore 639798, Singapore

2 Asian School of the Environment, Nanyang Technological University, Singapore 639798, Singapore

3 Present address: Department of Earth Sciences, University of Cambridge, Cambridge CB2 3EQ, UK

4 Department of Geography, Tokyo Metropolitan University, Tokyo 192-0397, Japan

5 Department of Geography, Swansea University, Swansea SA2 8PP, Wales, UK

6 V.I. Il'ichev Pacific Oceanological Institute FEB RAS, Vladivostok 690041, Russia

7 National Observation and Research Station of Jilin Changbaishan Volcano, Institute of Geology, China Earthquake Administration, Beijing 100029, China
$1000 \mathrm{~km}^{3}$; Volcanic Explosivity Index) eruption, and it is therefore recognized as one of the most powerful volcanic eruptions in recorded history (Newhall et al. 2018). There were two eruption phases during the ME, which produced comenditic and trachytic pyroclastic fall and flow deposits (Machida et al. 1990; Liu et al. 1998; Horn and Schmincke 2000). Tephra deposits from the ME were mainly dispersed to the east (Machida and Arai 1983), in line with the prevailing wind. Distal ash of the ME, also known as the Baegdusan-Tomakomai (B-Tm) ash, can be found as visible units within sedimentary sequences across the Sea of Japan and Japan (Fig. 1 and references therein), more than $1200 \mathrm{~km}$ from the volcano, and as a non-visible (cryptotephra) layer within the Greenland ice cores (Sun et al. 2014).

The total bulk volume of the eruption was previously estimated as $\sim 96-172 \mathrm{~km}^{3}$ (Liu et al. 1996; Liu et al. 1998; Horn and Schmincke 2000). Details on how estimates of 120 and $172 \mathrm{~km}^{3}$ (Liu et al. 1996; Liu et al. 1998) were derived were not given, and recent studies on eruptive products of the ME (e.g., McLean et al. 2016) have not been integrated to update or confirm previous volume estimates. These concerns motivate the present work, which reestimates the minimum and maximum total bulk volumes of the ME. We re-calculate minimum and maximum volumes of the B-Tm ash based on isopachs from previous studies and newly constructed isopachs. Minimum and maximum 
volumes of other eruptive products are assigned based on the most recent studies.

\section{The B-Tm ash}

We have compiled 76 thickness measurements (see Supplementing Document for raw data) of the B-Tm ash from previous works (Fig. 1; Utkin 1977; 1989; Machida and Arai 1983; Machida et al. 1990; Machida and Arai 2003;
Furukawa and Nanayama 2006; Okuno et al. 2011; Hughes et al. 2013; Chen et al. 2016; Ikehara et al. 2017; Derkachev et al. 2019; Nakanishi et al. 2020; Razjigaeva et al. 2020). Thickness data that are reported to be reworked or contain non-pyroclastic materials are excluded. The B-Tm ash was observed in the west of the volcano as cryptotephra (Sun et al. 2015), which cannot be used for helping isopach construction.

Horn and Schmincke (2000) and Machida and Arai (2003) previously constructed two sets of isopachs for the
Fig. 1 a, b B-Tm ash isopachs (solid lines; $\mathrm{cm}$ ) digitized from Horn and Schmincke (2000) and Machida and Arai (2003), respectively. Data sources marked in a. Dashed isopachs in $\mathrm{b}$ are constructed in this work; $\mathrm{c}$ constructed B-Tm ash extent (solid line) from Machida and Arai (2003) and 1-cm and $0.1-\mathrm{cm}$ isopachs from this work (dashed lines). Crosses are locations with no B-Tm ash observed (Furuta et al. 1986). See Supporting Document for more details on why they are not used to constrain the $0.1-\mathrm{cm}$ isopach constructed in this work
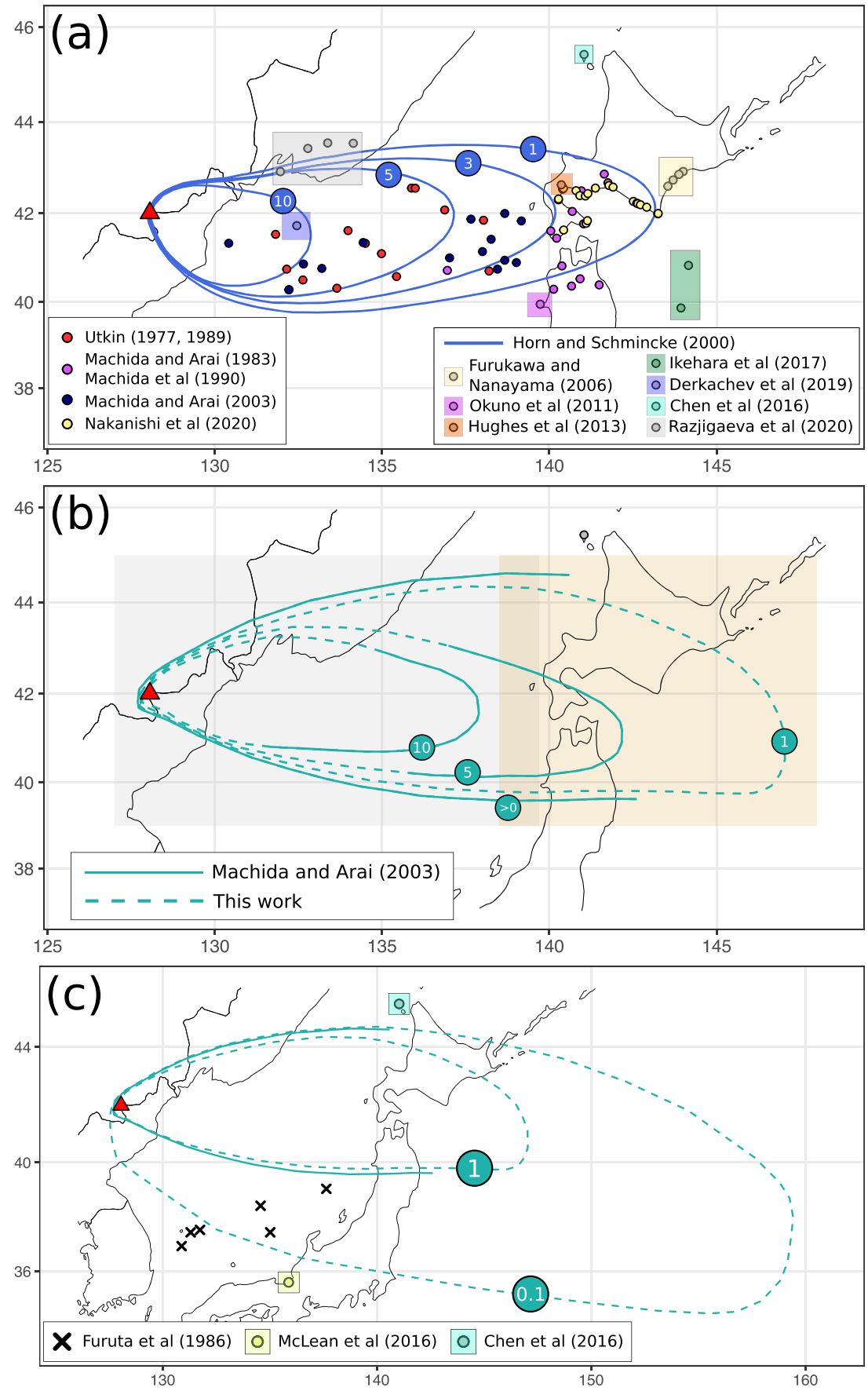
B-Tm ash (Fig. 1a and b). The former set has been used for volume calculation of the B-Tm ash. The latter only has the $10-\mathrm{cm}, 5-\mathrm{cm}$, and $>0-\mathrm{cm}$ isopachs, which are not fully enclosed. They have not been used for volume estimates. The B-Tm ash extent (i.e., the $>0-\mathrm{cm}$ isopach) from Machida and Arai (2003) will not be used here because the B-Tm ash has been found outside this extent: it was found as cryptotephra layer in Lake Kushu, northwest of Hokkaido (Chen et al. 2016) and a thin tephra layer $(<1$ $\mathrm{mm}$ ) in Lake Suigetsu, central Honshu (McLean et al. 2016) in Japan (Fig. 1c).

We complete the 10-cm and 5-cm isopachs of Machida and Arai (2003), which have much greater isopach areas (Table 1) than those published in Horn and Schmincke (2000). Additional $1-\mathrm{cm}$ and $0.1-\mathrm{cm}$ isopachs for the BTm ash (Fig. 1b and c, and Fig. 2) are also constructed (see Supplementing Document on how the isopachs are constructed) such that they could be combined with isopachs of Machida and Arai (2003) to estimate the maximum volume of the B-Tm ash. The $0.1-\mathrm{cm}$ isopach is constructed with uncertainty. How it would affect the maximum volume estimate will be examined.

\section{Comparing isopachs with thickness measurements}

Measured thicknesses of the B-Tm ash do not consistently thin with distance from the vent (Fig. 2). The cause of such a variability is not clear (e.g., varied dispersal patterns and post-depositional processes). It is thus difficult to estimate its volume accurately. Alternatively, if we prove that thicknesses predicted by the isopachs are mostly greater than individual thickness measurements, these isopachs can be used to calculate the maximum volume of the B-Tm ash. We are most interested in the maximum volume here because (1) isopachs of Machida and Arai (2003) have not been used for volume estimate, and they have much greater areas compared to those from Horn and Schmincke (2000); (2) a better-constrained maximum volume of the B-Tm ash could potentially help us confirm or reassign the VEI of the $\mathrm{ME}$ as the volume of the B-Tm ash takes up a large portion of the total eruption volume of the ME in previous studies (Table 2).

We compare thickness measurements of the B-Tm ash with isopachs of Machida and Arai (2003) and the newly constructed $1-\mathrm{cm}$ and $0.1-\mathrm{cm}$ isopachs, and find that within the $1-\mathrm{cm}$ isopach, there are 26,44 , and 4 thickness observations that are consistent, thinner, and thicker, respectively, than thicknesses inferred from the isopachs (Fig. 2; the other two thickness measurements are outside the 1-cm isopach shown in Fig. 1c). Thickness observations within the 10-cm isopach and north of $42^{\circ} \mathrm{N}$ (which corresponds to half of its area) are $3-\mathrm{cm}$ thick or thinner, suggesting that northern halves of the $10-\mathrm{cm}$ and 5-cm isopachs of Machida and Arai (2003) should have much smaller areas. These checks confirm that the isopachs of Machida and Arai (2003) and the newly constructed
Table 1 Isopach information of tephra fall deposits of the ME and the tephra from the 1815 Tambora eruption. Blue and red cells: isopach data used for volume calculation of the B-Tm ash. Yellow cells are isopach areas extrapolated based on the $10-\mathrm{cm}$ and $5-\mathrm{cm}$ isopachs assuming a linear relationship in the $\log$ (thickness) $-\sqrt{\text { isopach area }}$ plot. Isopach areas measured with the R package "geosphere" (R Core Team, 2017; Hijmans, 2019)

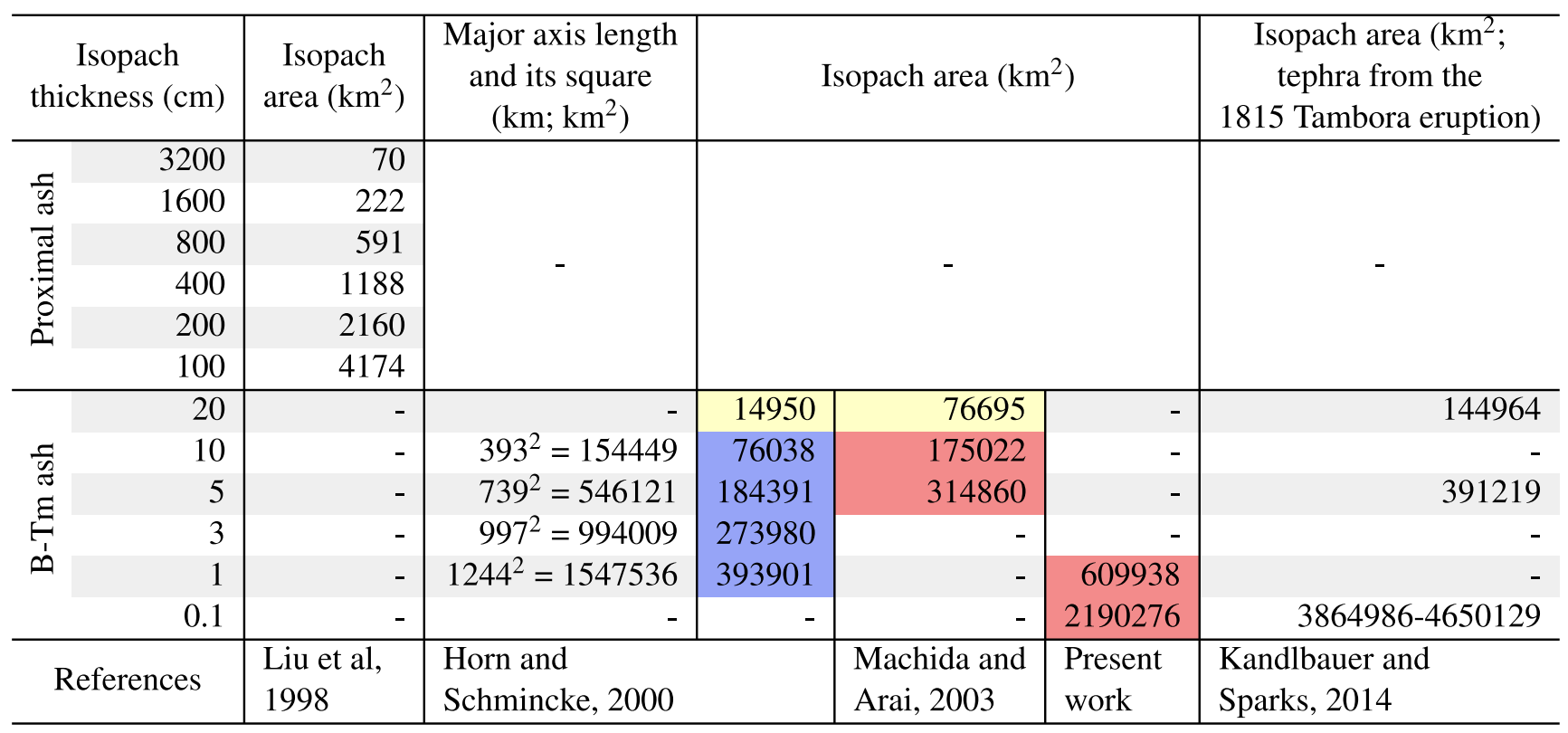


1-cm isopach can be reliably used for the maximum volume estimation of the B-Tm ash.

\section{Volume estimation}

Here we use the segmented exponential functions proposed by Fierstein and Nathenson (1992) to estimate the maximum volume of the B-Tm ash (Fig. 4). This method estimates the volume of tephra deposits by segments, and each segment is defined by the available isopachs. The volume within each segment is the volume of a tephra deposit from Isopach A to Isopach B. Exponential thinning is assumed within each segment on the $\log$ (thickness)- $\sqrt{\text { ispach area }}$ plot. This method is chosen because using other methods introduces additional uncertainties in fitting the isopach data to certain types of curves on the $\log$ (thickness)- $\sqrt{\text { ispach area }}$ plot (especially given just four data points), and the results might not represent the maximum estimate. In addition, volume of proximal tephra of the ME will be estimated separately later based on proximal isopachs. One main advantage of other methods (Pyle 1989; Bonadonna and Houghton 2005; Bonadonna and Costa 2012), i.e., the ability to infer the proximal thinning pattern of tephra deposits based on limited isopachs, would not apply to this work.

The volumes of the B-Tm ash calculated from isopachs of Horn and Schmincke (2000) and isopachs published by Machida and Arai (2003) plus our newly constructed ones are 26.66 and $62.48 \mathrm{~km}^{3}$, respectively, based on Eq.
Fig. 2 B-Tm ash observed thicknesses compared with isopachs shown in Fig. 1b and c. Extents of $\mathbf{a}$ and $\mathbf{b}$ correspond to gray and yellow panes in Fig. 1b, respectively. White, blue, and red points correspond to observations that are thinner, consistent, and thicker than thicknesses inferred from the isopachs. Observations masked by the gray box in $b$ are presented in a
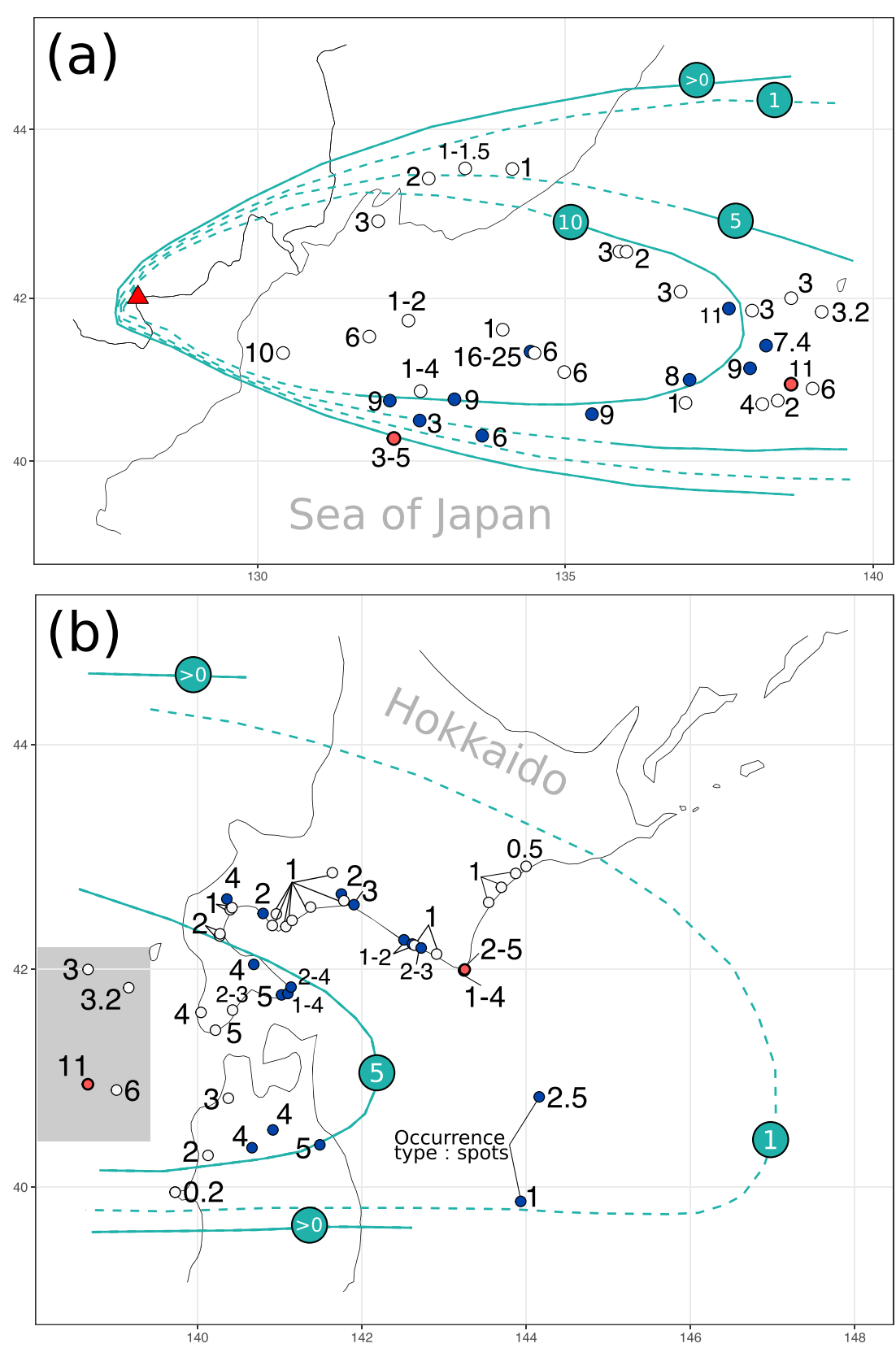
Table 2 Bulk volumes of different eruptive products of the ME and their sum from this work and previous studies

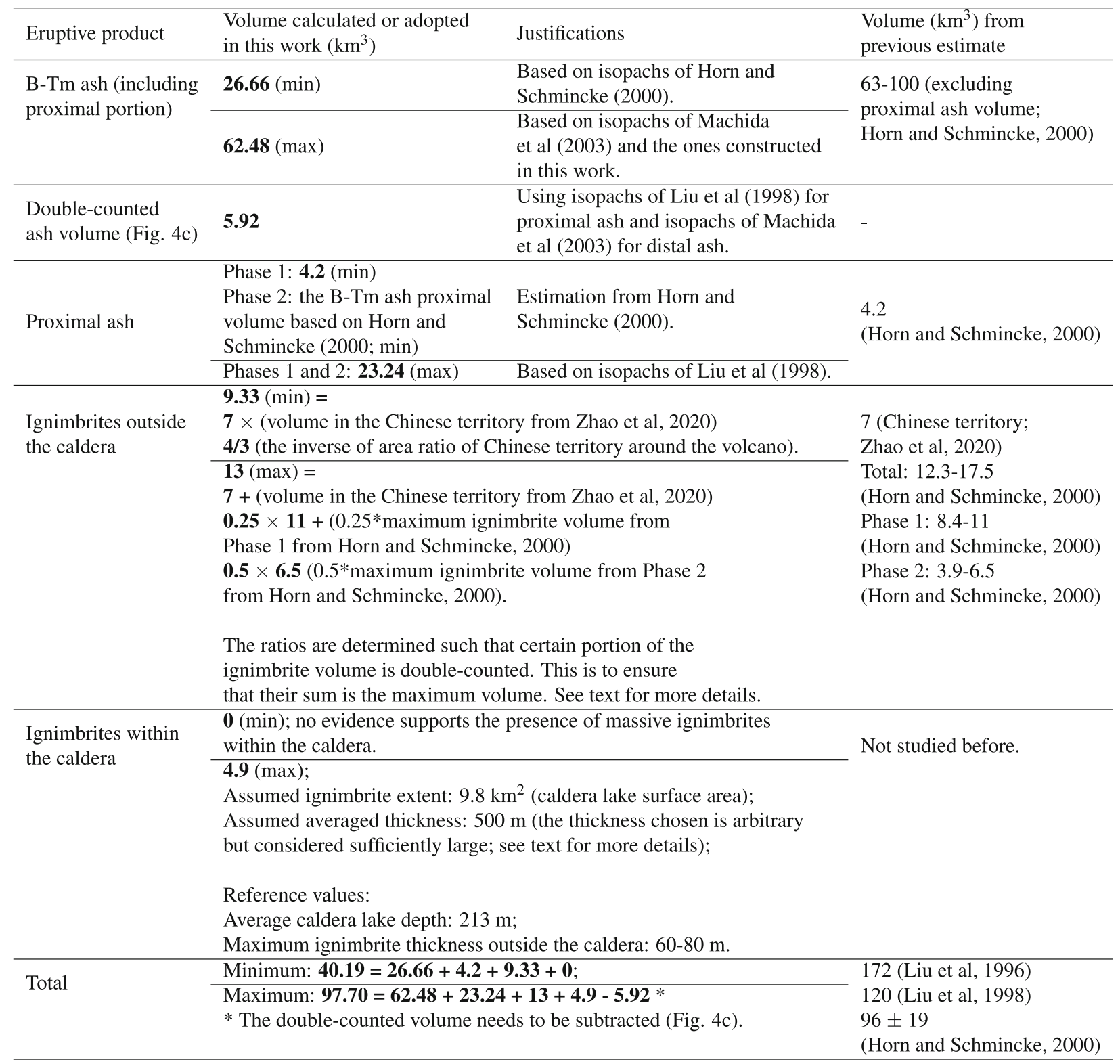

13 of Fierstein and Nathenson (1992). The one- and twosegment exponential functions of Pyle (1989) and Fierstein and Nathenson (1992) are applied to isopach data of Horn and Schmincke (2000) for better comparison as the same methods were used in their work, and the calculated volumes are 32.99 and $26.69 \mathrm{~km}^{3}$, respectively. The two values are within the range of $26.66-62.48 \mathrm{~km}^{3}$. It is noted that the reported volumes here include the volume of the proximal ash which is determined based on the distal $10-\mathrm{cm}$ and 5 -cm isopachs. In calculating the maximum total eruption volume later, this portion of volume will be replaced by the tephra volume calculated based on the proximal isopachs.

Our uncertainty in constructing the $1-\mathrm{cm}$ and $0.1-\mathrm{cm}$ isopachs has limited influence on the maximum volume estimate. $\mathrm{A} \pm 20 \%$ variation in both the $1-\mathrm{cm}$ and $0.1-\mathrm{cm}$ isopach areas leads to a $\pm 6.7 \%\left(58.29-66.59 \mathrm{~km}^{3}\right)$ variation in calculated maximum volume. $\mathrm{A} \pm 20 \%$ variation in the $0.1-\mathrm{cm}$ isopach area leads to a $\pm 2.9 \%\left(60.70-64.27 \mathrm{~km}^{3}\right)$ variation in calculated maximum volume.

\section{Comparison with previous studies and tephra deposit of the 1815 Tambora eruption}

The volume of the B-Tm ash was previously estimated as 63-100 $\mathrm{km}^{3}$ (Horn and Schmincke 2000). Using the same set of isopachs, our estimated volume is $26.66 \mathrm{~km}^{3}$. The estimated maximum volume from this work $\left(62.48 \mathrm{~km}^{3}\right)$ is close to but still below the previous lower limit, and the 
calculated volumes from our work also include the proximal volume which will be subtracted later in calculating the total eruption volume. Limited information was provided about how the previous volume was calculated, but we notice that with the one- and two-segment exponential functions of Fierstein and Nathenson (1992), using the longest isopach axis of Horn and Schmincke (2000) (Table 1), rather than of the square rooted isopach areas, results in volumes of 92.73 and $81.46 \mathrm{~km}^{3}$, respectively. These values are consistent with previous estimate, but overestimate the true volume due to using incorrect data.

Tephra volume of the 1815 Tambora eruption, the most recent VEI-7 eruption, was estimated to be $90-133 \mathrm{~km}^{3}$ (Self et al. 2004; Kandlbauer and Sparks 2014) using isopach-based methods. The isopach data of the tephra from the Tambora eruption reported in Kandlbauer and Sparks (2014) are compared with those of the B-Tm ash here. For the isopachs of Horn and Schmincke (2000) corresponding to our minimum B-Tm ash volume, their $20-\mathrm{cm}$ and $5-\mathrm{cm}$ isopach areas are $10.3 \%$ and $47.1 \%$ of those of the 1815 Tambora tephra deposit, respectively (Table 1). The ratios are $52.9 \%, 80.5 \%$, and $56.7 \%$ for the $20-\mathrm{cm}, 5-\mathrm{cm}$, and $0.1-\mathrm{cm}$ isopachs used for the maximum volume calculation (Table 1). The comparison confirms that the B-Tm ash volume was overestimated previously.

\section{Proximal tephra}

Liu et al. (1998) and Horn and Schmincke (2000) constructed isopachs for total and Phase 1 proximal tephras of the ME, respectively. The two sets lead to volume estimates of $21.66-23.24 \mathrm{~km}^{3}$ (with the one- and twosegment exponential models) and $4.2 \mathrm{~km}^{3}$ (Horn and Schmincke 2000), respectively.
The isopachs of Liu et al. (1998) are compared with the summed thicknesses of tephra deposits from the ME reported in recent works (Machida et al. 1990; Sun et al. 2017; Pan et al. 2020) at sample sites to the east of the volcano (Fig. 3). Thicknesses of potentially post-ME tephras (due to the dispute over the presence of post-ME eruptions; Wei et al. 2013; Sun et al. 2017; Pan et al. 2017; Pan et al. 2020) are also included as we are more concerned with the maximum thickness. All available observations are at least $50-250 \mathrm{~cm}$ thinner than predictions from the isopachs, showing that in the east of the volcano, isopachs of Liu et al. (1998) greatly overestimate the tephra thickness distribution.

We thus use $23.24 \mathrm{~km}^{3}$ to denote the maximum volume of the proximal ME tephra (i.e., the sum of Phase 1 and 2 volumes). We use $4.2 \mathrm{~km}^{3}$ and the proximal volume of the B-Tm ash calculated based on isopachs of Horn and Schmincke (2000) to denote minimum volumes of the proximal Phase 1 and 2 tephras, respectively. The latter is adopted because studies have confirmed the presence of Phase 2 tephra close to the vent (Machida et al. 1990; Pan et al. 2017), and tephra thickness tends to have a greater thinning rate in the area close to the vent (Pyle 1989).

\section{Extra-caldera ignimbrites}

Horn and Schmincke (2000) estimated that the volume of the ME ignimbrites ranged from 12.3 to $17.5 \mathrm{~km}^{3}$ (Phase 1: $8.4-11 \mathrm{~km}^{3}$; Phase 2: 3.9-6.5 $\mathrm{km}^{3}$ ). Zhao et al. (2020) estimated that the volume in China was $\sim 7 \mathrm{~km}^{3}$ (Fig. 3), and found that extents of the ignimbrites in China are smaller than those mapped by Horn and Schmincke (2000).

Here the maximum extra-caldera ignimbrite volume is assumed to be $13 \mathrm{~km}^{3}$, which is the sum of the volume in China ( $7 \mathrm{~km}^{3}$; Zhao et al. 2020$)$, a quarter $(11 \times 0.25=2.75$
Fig. 3 Proximal ME tephra isopachs (unit: $\mathrm{cm}$ ) from Liu et al. (1998). Total thicknesses (cm) of ME tephras digitized from recent works are marked with references given. Fall deposits that might be from post-ME eruptions (due to the dispute over the presence of post-ME eruptions) are treated as ME tephras. Inset figure shows the extent of the main figure with reference countries and region labeled

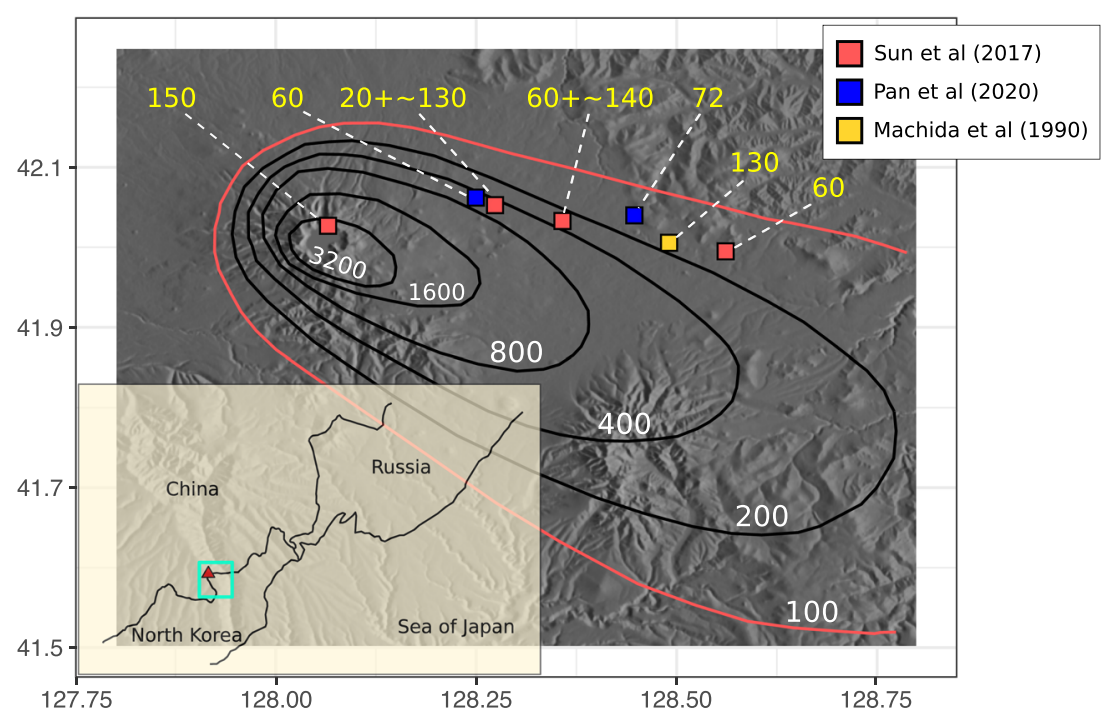


$\mathrm{km}^{3}$ ) of maximum Phase 1 ignimbrite volume estimated by Horn and Schmincke (2000), and half $(6.5 \times 0.5=3.25$ $\mathrm{km}^{3}$ ) of maximum Phase 2 ignimbrite volume estimated by (Horn and Schmincke 2000; Table 2). The latter two denote the assumed Phases 1 and 2 extra-caldera ignimbrite volumes in North Korea because Horn and Schmincke (2000) estimated that Phase 1 ignimbrite covered a half circle area to the north around the vent (Fig. 2 in their work), which is mostly in China, suggesting that the Phase 1 ignimbrite extent in North Korea must be smaller than a quarter of its total area (the southeast quadrant with respect to the vent is within the North Korean territory); the area ratio of Phase 2 ignimbrite in North Korea is smaller than half of its total area as mapped by Horn and Schmincke (2000). The proposed volume thus maximizes volumes of the ME ignimbrites in North Korea, and takes into account the most recent and more detailed estimate of their volume in China. The minimum extra-caldera ignimbrite volume is assumed to be $9.33 \mathrm{~km}^{3}$, which is the estimated volume in China from Zhao et al. (2020) times the inverse of its area ratio $(3 / 4)$ in China around the volcano.

\section{Intra-caldera ignimbrites}

No published studies suggest that a large portion of ignimbrites was preserved within the caldera or indicate significant ponding of ignimbrites during the ME. The intra-caldera ignimbrite volume from the ME has not been considered in previous works. Assigning its value is thus subject to significant uncertainty. No ME ignimbrites can be found at the currently exposed inner caldera wall. Within the caldera and above the caldera lake level, pyroclastic deposits prior to the ME are exposed (Wei et al. 2013). Pyroclastic fall, flow, and surge deposits that were deposited either from or after the ME (Wei et al. 2013) are locally exposed, suggesting that the extent of massive and thick intra-caldera ignimbrites, if present, cannot exceed the caldera lake surface. Here a dummy volume of $4.9 \mathrm{~km}^{3}$, the product of the caldera lake surface area $\left(9.8 \mathrm{~km}^{2}\right)$ and an assumed thickness of $500 \mathrm{~m}$, is used to denote the maximum intracaldera ignimbrite volume. The thickness chosen is arbitrary but is considered sufficiently large. We note here that the average depth of the caldera lake today is $213 \mathrm{~m}$. The minimum intra-caldera ignimbrite volume is set to be $0 \mathrm{~km}^{3}$, which is a more likely estimate given evidence listed above.

\section{Total volume, VEI, and magnitude of the ME}

Minimum and maximum total bulk volumes of the ME are calculated as 40.19 and $97.70 \mathrm{~km}^{3}$, respectively, based on volumes assigned for each eruptive product stated above (Table 2). In calculating the maximum, after taking the sum, the double-counted volume of proximal ash and the B-Tm ash is subtracted (Fig. 4c). It is stressed that the volume range is defined based on the minimum and maximum total volumes of the ME, not \pm one or two standard deviations from the mean. The maximum volume is estimated based on maximized volumes of all eruptive products of the ME: we have proved that isopachs of the proximal ash and the B-Tm ash used for their maximum volume calculation greatly overestimate their thickness distributions; ignimbrite volumes are also maximized in calculating the maximum total volume, and a dummy volume for intra-caldera ignimbrites, which is highly likely to be a lot greater than their true volume if present, is assumed and included as well. The true total volume of the ME thus has to be a lot smaller than $97.7 \mathrm{~km}^{3}$.

One well-accepted total eruption volume of the $\mathrm{ME}$ is $96 \pm 19 \mathrm{~km}^{3}$, which was calculated by assuming a volume range of $63-100 \mathrm{~km}^{3}$ for the B-Tm ash (Horn and Schmincke 2000), but its volume is updated to $26.66 \mathrm{~km}^{3}$ based on the same isopachs in this work. We therefore conclude that the ME is a VEI-6 (10-100 $\mathrm{km}^{3}$ ) eruption, rather than VEI-7 as widely assumed in previous studies.

The magnitude of the ME has been assumed to be 7.4 previously (Hayakawa and Koyama 1998). Estimating its magnitude accurately is difficult because robust data on bulk densities of different eruptive materials are currently not available. We estimate updated magnitude values by somewhat arbitrarily assuming average bulk densities of 1500,1000 , and $600 \mathrm{~kg} / \mathrm{m}^{3}$. Given the updated maximum volume of $97.7 \mathrm{~km}^{3}$, the magnitudes are estimated as 7.2 , 7.0, and 6.8; the corresponding values are 6.8, 6.6, and 6.4 if the minimum volume $\left(40.19 \mathrm{~km}^{3}\right)$ is used for calculation. The above calculation suggests that the magnitude of the ME must be lower than 7.4, and its true value lies somewhere in between 6.4 and 7.2.

\section{Significance}

The previously estimated eruption volume ( $\left.\sim 96-172 \mathrm{~km}^{3}\right)$ has been used in all previous studies on the ME, its eruptive products, and how the eruption interacted with global climate. It is imperative to update the eruption volume of the $\mathrm{ME}$ to the more robust and evidence-based estimate of 40.19-97.90 $\mathrm{km}^{3}$ from this work.

Revising the VEI of the ME from 7 to 6 indicates that there are only two, rather than three, VEI-7 eruptions (i.e., the 1257 Samalas eruption and the 1815 Tambora eruption; Newhall et al. 2018) in the last 2000 years. Our updated eruption volume of the ME also suggests that its magnitude 

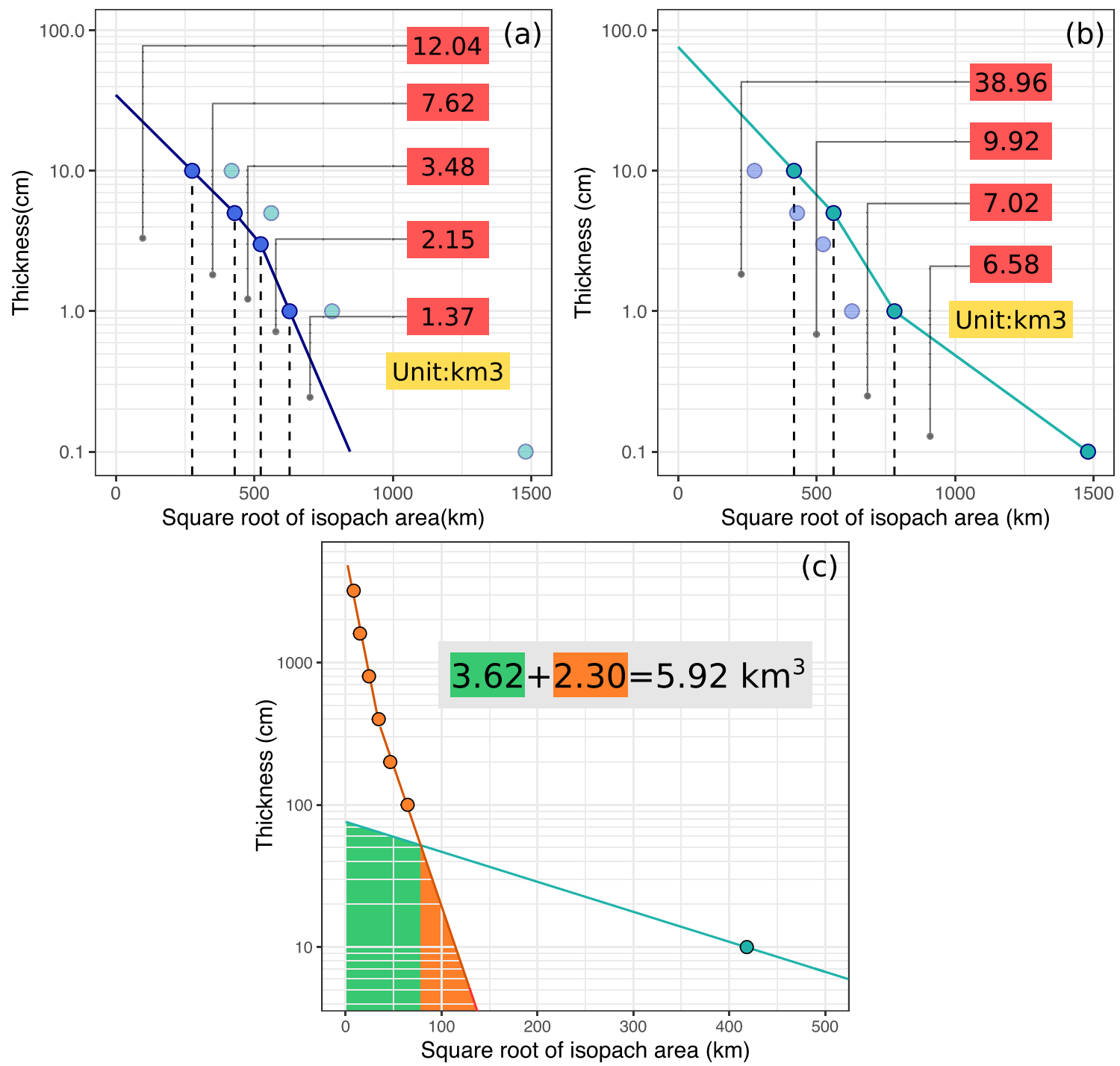

Fig. 4 Log(thickness) $-\sqrt{\text { isopach area }}$ plots. a Isopach data from Horn and Schmincke (2000); b isopach (10-cm and 5-cm) data from Machida and Arai (2003) and the present work (1-cm and 0.1-cm). Tephra volumes in different square roots of isopach area ranges are marked; c: proximal isopach data (orange points and lines) of the ME based on Liu et al. (1998). Green point: the 10-cm B-Tm ash

is lower than previously thought. These suggest that global magnitude-frequency relationships for the most recent large explosive volcanic eruptions need to be revised.

The ME had limited regional climatic effects, rather than global or hemispheric impact (Xu et al. 2013). Global volcanic aerosol forcing by the ME was smaller than that from the 1815 Tambora eruption (Sigl et al. 2015), although sulfur released from the ME might be greater than the Tambora eruption (Iacovino et al. 2016). These two seemingly conflicted arguments might be partially resolved by our work, which shows that sulfur released from the eruption might be overestimated in previous studies as it was calculated based on a total volume $\left(96 \mathrm{~km}^{3}\right.$ estimated from isopach data of Machida and Arai (2003). Green line: the thinning pattern based on 10-cm and 5-cm isopachs of Machida and Arai (2003). Shaded areas correspond to double-counted volumes in calculating the total ME tephra volume. Their volumes are labeled with corresponding colors. All isopach data given in Table 1

(Horn and Schmincke 2000)) that is close to the maximum volume estimated in this work.

Supplementary information The online version contains supplementary material available at https://doi.org/10.1007/s00445-021-01487-8.

Acknowledgements We thank Dr. Fierstein and two anonymous reviewers for their constructive and insightful comments on this manuscript. We thank Dr. Fierstein for handling our manuscript. We thank H. U. Schmincke for kindly sharing information about the Millennium Eruption and S. Uesawa for helping us with information about the B-Tm ash in Japanese. This work comprises Earth Observatory of Singapore contribution no. 365.

Funding Q. Yang, S.F. Jenkins, and G.A. Lerner were partly supported by the National Research Foundation Singapore and the Singapore 
Ministry of Education under the Research Centres of Excellence initiative (Project Number: NRF2018NRF-NSFC003ES-010). G.A. Lerner was partly supported by the funding from the AXA Joint Research Initiative under the project "Volcanic Risk Assessment in Asia". J. Xu was partly supported by the National Natural Science Foundation of China (Grant No. 41861144025). This work forms part of a jointly funded collaboration (NRF-NSFC) between Q. Yang, S.F. Jenkins, and G.A. Lerner at the Asian School of the Environment/Earth Observatory of Singapore at NTU and H. Wei, J. Xu, and B. Pan at the Chinese Earthquake Administration.

Open Access This article is licensed under a Creative Commons Attribution 4.0 International License, which permits use, sharing, adaptation, distribution and reproduction in any medium or format, as long as you give appropriate credit to the original author(s) and the source, provide a link to the Creative Commons licence, and indicate if changes were made. The images or other third party material in this article are included in the article's Creative Commons licence, unless indicated otherwise in a credit line to the material. If material is not included in the article's Creative Commons licence and your intended use is not permitted by statutory regulation or exceeds the permitted use, you will need to obtain permission directly from the copyright holder. To view a copy of this licence, visit http://creativecommons. org/licenses/by/4.0/.

\section{References}

Bonadonna C, Costa A (2012) Estimating the volume of tephra deposits: a new simple strategy. Geol 40(5):415-418

Bonadonna C, Houghton B (2005) Total grain-size distribution and volume of tephra-fall deposits. Bull Volcanol 67(5):441-456

Chen X-Y, Blockley SP, Tarasov PE, Xu Y-G, McLean D, Tomlinson EL, Albert PG, Liu J-Q, Müller S, Wagner M et al (2016) Clarifying the distal to proximal tephrochronology of the Millennium (B-Tm) eruption, Changbaishan Volcano, Northeast China. Quat Geochronol 33:61-75

Derkachev A, Utkin I, Nikolaeva N, Gorbarenko S, Portnyagin M, Sakhno V, Malakhova G, Shi X, Lv H (2019) Tephra layers of large explosive eruptions of Baitoushan/Changbaishan Volcano in the Japan Sea sediments. Quat Int 519:200-214

Fierstein J, Nathenson M (1992) Another look at the calculation of fallout tephra volumes. Bulletin of volcanology 54(2):156-167

Furukawa R, Nanayama F (2006) Holocene pyroclastic fall deposits along the Pacific coastal region of eastern Hokkaido. Kazan 51(6):351-371

Furuta T, Fujioka K, Arai F (1986) Widespread submarine tephras around Japan-petrographic and chemical properties. Mar Geol 72(1-2):125-142

Hayakawa Y, Koyama M (1998) Dates of two major eruptions from towada and baitoushan in the 10th century. Bull. Volcanol. Soc. Jpn, 43(5)

Hijmans RJ (2019) geosphere: Spherical Trigonometry. https://CRAN. $\mathrm{R}$-project.org/package=geosphere. $\mathrm{R}$ package version 1.5-10

Horn S, Schmincke H-U (2000) Volatile emission during the eruption of Baitoushan Volcano (China/North Korea) ca. 969 AD. Bull Volcanol 61(8):537-555

Hughes PD, Mallon G, Brown A, Essex H, Stanford J, Hotes S (2013) The impact of high tephra loading on late-Holocene carbon accumulation and vegetation succession in peatland communities. Quat Sci Rev 67:160-175

Iacovino K, Ju-Song K, Sisson T, Lowenstern J, Kuk-Hun R, JongNam J, Kun-Ho S, Song-Hwan H, Oppenheimer C, Hammond JO et al (2016) Quantifying gas emissions from the "Millennium
Eruption" of Paektu volcano, Democratic People's Republic of Korea/China. Science advances 2(11):e1600913

Ikehara K, Usami K, Kanamatsu T, Danhara T, Yamashita T (2017) Three important Holocene tephras off the Pacific coast of the Tohoku region Northeast japan: Implications for correlating onshore and offshore event deposits. Quat Int 456:138-153

Kandlbauer J, Sparks R (2014) New estimates of the 1815 Tambora eruption volume. J Volcanol Geotherm Res 286:93-100

Liu R-X, Wei H-Q, Tang J, Song S, Li X, Yang Q, Liu T, Wang J (1996) Progress of the study on Tianchi volcano, Changbaishan, China. Seismol Geomagn Obs Res 17(4):2-11

Liu R-X, Wei H-Q, Li J-T et al (1998) Recent eruptions of the Changbaishan Tianchi Volcano. Sci. Press, Beijing, p 165

Machida H, Arai F (1983) Extensive ash falls in and around the Sea of Japan from large late Quaternary eruptions. J Volcanol Geotherm Res 18(1-4):151-164

Machida H, Arai F (2003) Atlas of Tephra in and Around Japan [revised edition] University of Tokyo Press

Machida H, Moriwaki H, Zhao D-C (1990) The recent major eruption of Changbai Volcano and its environmental effects. Geographical Reports of Tokyo Metropolitan University 25:1-20

McLean D, Albert PG, Nakagawa T, Staff RA, Suzuki T, Smith VC et al (2016) Identification of the Changbaishan 'Millennium'(B$\mathrm{Tm}$ ) eruption deposit in the Lake Suigetsu (SG06) sedimentary archive, Japan: synchronisation of hemispheric-wide palaeoclimate archives. Quat Sci Rev 150:301-307

Nakanishi R, Ashi J, Okamura S (2020) A dataset for distribution and characteristics of Holocene pyroclastic fall deposits along the Pacific coasts in western Hokkaido, Japan. Data Data in Brief 33:106565

Newhall C, Self S, Robock A (2018) Anticipating future Volcanic Explosivity Index (VEI) 7 eruptions and their chilling impacts. Geosphere 14(2):572-603

Okuno M, Torii M, Yamada K, Shinozuka Y, Danhara T, Gotanda K, Yonenobu H, Yasuda Y (2011) Widespread tephras in sediments from lake Ichi-no-Megata in northern japan: Their description, correlation and significance. Quat Int 246(1-2):270-277

Oppenheimer C, Wacker L, Xu J, Galván JD, Stoffel M, Guillet S, Corona C, Sigl M, Di Cosmo N, Hajdas I et al (2017) Multi-proxy dating the 'Millennium Eruption' of Changbaishan to late $946 \mathrm{CE}$. Quat Sci Rev 158:164-171

Pan B, de Silva SL, Xu J, Chen Z, Miggins DP, Wei H (2017) The VEI-7 Millennium eruption, Changbaishan-Tianchi volcano china/DPRK: New field, petrological, and chemical constraints on stratigraphy, volcanology, and magma dynamics. J Volcanol Geotherm Res 343:45-59

Pan B, de Silva SL, Xu J, Liu S, Xu D (2020) Late Pleistocene to present day eruptive history of the Changbaishan-Tianchi Volcano china/DPRK: New field, geochronological and chemical constraints. J Volcanol Geotherm Res 399:106870

Pyle DM (1989) The thickness, volume and grainsize of tephra fall deposits. Bull Volcanol 51(1):1-15

R Core Team (2017) R: A Language and Environment for Statistical Computing. R Foundation for Statistical Computing, Vienna, Austria. https://www.R-project.org/

Razjigaeva N, Ganzey L, Grebennikova T, Mokhova L, Arslanov KA, Maksimov F, Petrov AY, Sakhno V (2020) B-Tm Ash of a Catastrophic Eruption of Baitoushan Volcano in Terrestrial Deposits of Primorye as an Age Marker of the Medieval Warm Period in the Holocene. In: Doklady Earth Sciences, volume 494, pages 779-786. Springer

Self S, Gertisser R, Thordarson T, Rampino M, Wolff J (2004) Magma volume, volatile emissions, and stratospheric aerosols from the 1815 eruption of tambora. Geophysical Research Letters, $31(20)$ 
Sigl M, Winstrup M, McConnell JR, Welten KC, Plunkett G, Ludlow F, Büntgen U, Caffee M, Chellman N, Dahl-Jensen D et al (2015) Timing and climate forcing of volcanic eruptions for the past 2,500 years. Nature 523(7562):543-549

Sun C, Plunkett G, Liu J, Zhao H, Sigl M, McConnell JR, Pilcher JR, Vinther B, Steffensen J, Hall V (2014) Ash from changbaishan millennium eruption recorded in Greenland ice: implications for determining the eruption's timing and impact. Geophys Res Lett 41(2):694-701

Sun C, You H, He H, Zhang L, Gao J, Guo W, Chen S, Mao Q, Liu Q, Chu G et al (2015) New evidence for the presence of Changbaishan Millennium eruption ash in the Longgang volcanic field, Northeast China. Gondwana Res 28(1):52-60

Sun C, Liu J, You H, Nemeth K (2017) Tephrostratigraphy of Changbaishan volcano, northeast China, since the mid-Holocene. Quat Sci Rev 177:104-119
Utkin I (1977) Personal archive of the Laboratory of Sedimentology and Stratigraphy of the Pacific Oceanological Institute

Utkin I (1989) Sedimentation and burial of pyroclastics on the bottom: Deep sea basins in the Sea of Japan. Periokeanicheskiy sedimentogenez (Perioceanic Sedimentogenesis), pp 67-79

Wei H, Liu G, Gill J (2013) Review of eruptive activity at Tianchi volcano Changbaishan, northeast china: implications for possible future eruptions. Bulletin of volcanology 75(4):1-14

Xu J, Pan B, Liu T, Hajdas I, Zhao B, Yu H, Liu R, Zhao P (2013) Climatic impact of the Millennium eruption of Changbaishan volcano in china: New insights from high-precision radiocarbon wiggle-match dating. Geophys Res Lett 40(1):54-59

Zhao B, Xu J, Yu H, Chen Z (2020) pyroclastic density current facies in the millennium eruption of tianchi volcano northeast china: insights from topography, stratigraphy, granulometry and petrography. Frontiers in Earth Science 8:323 